Cavanaugh-Hussey MW, Berry JD, Lloyd-Jones DM (2008) Who exceeds ATPIII risk thresholds? Systematic examination of the effect of varying age and risk factor levels in the ATP-III risk assessment tool. Prev Med 47: 619-623.

Cooney MT, Dudina A, D’Aogstino R, Graham IM (2010) Cardiovascular risk-estimation systems in primary prevention: do they differ? Do they make a difference? Can we see the future? Circulation 122: 300-310.

de Haas EC, Altena R, Boezen HM, Zwart N, Smit AJ, Bakker JL, van Roon AM, Postma A, Wolffenbuttel BHR, Hoekstra HJ, van Leeuwen FE, Sleiffer DT, Gietema JA (2013) Early development of the metabolic syndrome after chemotherapy for testicular cancer. Ann Oncol 24: 749-755.

Gami AS, Witt BJ, Howard DE, Erwin PJ, Gami LA, Somers VK, Montori VM (2007) Metabolic syndrome and the risk of incident cardiovascular events and death: a systematic reviewand meta-analysis of longitudinal studies. J Am Coll Cardiol 49: 403-414.

Graham I, Atar D, Borch-Johnsen K, Boysen G, Burell G, Cifkova R, Dallongeville J, De Backer G, Ebrahim S, Gjelsvik B, Herrmann-Lingen C, Hoes A, Humphries S, Knapton M, Perk J, Priori SG, Pyorala K, Reiner Z, Ruilope L, Sans-Menendez S, Op Reimer WS, Weissberg P, Wood D, Yarnell J, Zamorano JL, Walma E, Fitzgerald T, Cooney MT, Dudina A, Vahanian A, Camm J, De Caterina R, Dean V, Dickstein K, Funck-Brentano C, Filippatos G, Hellemans I, Kristensen SD, McGregor K, Sechtem U, Silber S, Tendera M, Widimsky P, Zamorano JL, Altiner A, Bonora E, Durrington PN, Fagard R, Giampaoli S, Hemingway H, Hakansson J, Kjeldsen SE, Larsen L, Mancia G, Manolis AJ, Orth-Gomer K, Pedersen T, Rayner M, Ryden L, Sammut M, Schneiderman N, Stalenhoef AF, Tokgozoglu L, Wiklund O, Zampelas A (2007) European guidelines on cardiovascular disease prevention in clinical practice: full text: fourth joint task force of the European Society of Cardiology and other societies on cardiovascular disease prevention in clinical practice (constituted by representatives of nine societies and by invited experts). Eur J Cardiovasc Prev Rehabil 14(suppl 2): S1-S113.

Haugnes HS, Aass N, Fossa SD, Dahl O, Klepp O, Wist EA, Svartberg J, Wilsgaard T, Bremnes RM (2007) Components of metabolic syndrome in long-term survivors of testicular cancer. Ann Oncol 18: 241-248.

Huddart RA, Norman A, Moynihan C, Horwich A, Parker C, Nicholls E, Dearnaley DP (2005) Fertility, gonadal and sexual function in survivors of testicular cancer. Br J Cancer 93: 200-207.

Huddart RA, Norman A, Shahidi M, Horwich A, Coward D, Nicholls I, Dearnaley DP (2003) Cardiovascular disease as a long- term complication of treatment of testicular cancer. J Clin Oncol 21: 1513-1523.

Nuver J, Smit AJ, Wolffenbuttel BHR, Sluiter J, Hoekstra HJ, Sleijfer DT, Gietema JA (2005) The metabolic syndrome and disturbances in hormone levels in long-term survivors of disseminated testicular cancer. J Clin Oncol 23: 3718-3725.

van As NJ, Gilbert DC, Money-Kyrle J, Bloomfield D, Beesley S, Dearnaley DP, Horwich A, Huddart RA (2008) Evidence-based pragmatic guidelines for the follow-up of testicular cancer: optimising the detection of relapse. Br J Cancer 98: 1894-1902.

Willemse PM, Burggraaf J, Hamdy NAT, Weijl NI, Vossen CY, van Wulften L, van Steijn-van Tol AQMJ, Rosendaal FR, Osanto S (2013) Prevalence of the metabolic syndrome and cardiovascular disease risk in chemotherapytreated testicular germ cell tumour survivors. Br J Cancer 109: 60-67.

(1) (2) (2) This work is licensed under the Creative Commons BY $\mathrm{NG}$ SA Attribution-NonCommercial-Share Alike 3.0 Unported License. To view a copy of this license, visit http://creativecommons. org/licenses/by-nc-sa/3.0/

\title{
$\mathrm{BJC}$
}

\section{Reply: 'Comment on Prevalence of the metabolic syndrome and cardiovascular disease risk in chemotherapy-treated testicular germ cell tumour survivors'}

\author{
P M Willemse ${ }^{1}$, J Burggraaf ${ }^{2}$, N A T Hamdy ${ }^{3}$ and S Osanto*,1 \\ ${ }^{1}$ Department of Clinical Oncology, Leiden University Medical Center, Albinusdreef 2, 2333 Leiden, ZA, The Netherlands; \\ ${ }^{2}$ Centre for Human Drug Research, Zernikedreef 10, 2333 Leiden, CL, The Netherlands and ${ }^{3}$ Department of Endocrinology and \\ Metabolic Diseases, Leiden University Medical Center, Albinusdreef 2, 2333 Leiden, ZA, The Netherlands
}

We read with interest the Letter to the Editor by Singhera and Huddart (2013) and are pleased to respond to their comments.

Regarding their comments on missing data, the median followup time after completing treatment seems to have escaped their attention, as it was provided for all survivors and for separate treatment groups in Table 2 of our published article (Willemse et al, 2013).
We indeed had omitted to report on the actual number of survivors on antihypertensive, lipid modifying and/or antidiabetic medication, but did not exclude survivors on one or more of these medications from the analysis in calculating the 10-year risk of cardiovascular disease. In fact, the 36 survivors, with a median age of 50.7 years (range 29.5-69.5), who received cardiac-modifying medication had a Framingham Risk Score (FRS) and Systemic 
Coronary Risk Examination (SCORE) risk of 4.7\% (interquartile range, IQR $0.8-2.7$ ) and $7.9 \%$ (IQR 3.5-12.0), respectively, underscoring that Metabolic Syndrome (MetS) does indeed represent a risk factor for cardiovascular disease (CVD). Excluding these cardiac medication using survivors would decrease the 10-year FRS and SCORE risk to 2.2\% (IQR 0.0-3.0) and 1.1\% (IQR $0.1-1.1$ ), respectively, in the remaining 215 patients, clearly demonstrating that the 'low FRS and SCORE risk' were not diluted due to the inclusion of survivors on anticardiac medication as suggested by the authors of the Letter. Although we assume that the definition for healthy controls as being subjects without any disease and receiving no treatment is globally accepted, we are happy to confirm that indeed none of the controls were on anticardiac medication.

As we acknowledged in our discussion that increased MetS prevalence in the survivors may not translate into increased 10 -year FRS and SCORE predicted CVD risk because of short follow-up time and young survivors' age, we fail to understand the concerns expressed by Singhera and Huddart (2013) in their Letter. In addition, the calculated CVD risks are corroborated by our center's unpublished cardiovascular incidence data in testicular germ cell tumour (GCT) patients treated between 1977 and 2008. Of the 776 GCT patients included in the hospital's cancer registry during this 31-year period, 65 had died of testicular cancer, while 221 were discharged from follow-up. Of the remaining 490 survivors with a complete data set, 65 had died during follow-up: 3 of a myocardial infarction, 1 of a cerebrovascular event, 33 of second malignancies, 28 of other causes of death. Of the 425 patients currently alive and under regular follow-up, 5 had a nonfatal myocardial infarction, 4 had a non-fatal CVA, and 4 an acute coronary syndrome. Seventeen of 490 patients (3.5\%) had thus a cardiovascular event at a median age of 51.4 years (23-67 year), 0.1-29 years (median 12.5 year) after their anticancer treatment. Fifteen of seventeen patients with a cardiovascular event had received combination chemotherapy in the past. This 'low' actual CVD incidence corresponds to the 'low' (3\%) 10-year FRS cardiovascular risk estimate in the 251 patients reported in our article (Willemse et al, 2013).

We welcome the suggestion of undertaking a more pertinent lifetime risk rather than 10-year risk analysis, but are not aware of the existence of a validated predictive risk calculation model for the former. The alternative option recommended by Singhera and Huddart (2013) to use relative risk charts for counselling survivors regarding CVD risk (Graham et al, 2007) actually represents no alternative option to ours, as Graham et al (2007) also uses the SCORE risk used by us in determining CVD risk (Willemse et al, 2013). We do agree, however, that large-scale longitudinal cohort studies on CVD in cancer survivors should be of benefit as they would provide more accurate data on lifetime CVD risk in GCT survivors.

In keeping with the figure of $12-16 \%$ of GCT survivors with complete hypogonadism quoted by Huddart and Singhera (2013) in their Letter, 34 (12.9\%) of our cohort of GCT survivors also had complete hypogonadism, whereas 42 survivors (15.9\%) had partial hypogonadism.

Based on the biological activity of androgens in the male, the morbidity of low androgen levels and efficacy of testosterone in reducing MetS prevalence and CVD mortality (Rebuffe-Scrive et al, 1991; Marin et al, 1993; Anderson et al, 1996; Boyanov et al, 2003; Kapoor et al, 2006; Heufelder et al, 2009; Jones et al, 2011), we would strongly argue that there is no justifiable reason to withhold androgen replacement therapy from male GCT survivors with complete hypogonadism. While the results of randomised testosterone replacement trials in cancer survivors are eagerly awaited, the clock is ticking for GCT survivors who are at clear risk of developing significant morbidity related to long-term androgen deficiency.

\section{REFERENCES}

Anderson FH, Francis RM, Faulkner K (1996) Androgen supplementation in eugonadal men with osteoporosis-effects of 6 months of treatment on bone mineral density and cardiovascular risk factors. Bone 18: 171-177.

Boyanov MA, Boneva Z, Christov VG (2003) Testosterone supplementation in men with type 2 diabetes, visceral obesity and partial androgen deficiency. Aging Male 6: 1-7.

Graham I, Atar D, Borch-Johnsen K, Boysen G, Burell G, Cifkova R, Dallongeville J, De BG, Ebrahim S, Gjelsvik B, Herrmann-Lingen C, Hoes A, Humphries S, Knapton M, Perk J, Priori SG, Pyorala K, Reiner Z, Ruilope L, Sans-Menendez S, Op Reimer WS, Weissberg P, Wood D, Yarnell J, Zamorano JL, Walma E, Fitzgerald T, Cooney MT, Dudina A, Vahanian A, Camm J, De CR, Dean V, Dickstein K, Funck-Brentano C, Filippatos G, Hellemans I, Kristensen SD, McGregor K, Sechtem U, Silber S, Tendera M, Widimsky P, Zamorano JL, Altiner A, Bonora E, Durrington PN, Fagard R, Giampaoli S, Hemingway H, Hakansson J, Kjeldsen SE, Larsen M, Mancia G, Manolis AJ, Orth-Gomer K, Pedersen T, Rayner M, Ryden L, Sammut M, Schneiderman N, Stalenhoef AF, Tokgozoglu L, Wiklund O, Zampelas A (2007) European guidelines on cardiovascular disease prevention in clinical practice: full text. Fourth Joint Task Force of the European Society of Cardiology and other societies on cardiovascular disease prevention in clinical practice (constituted by representatives of nine societies and by invited experts). Eur J Cardiovasc Prev Rehabil 14(Suppl 2): S1-113.

Heufelder AE, Saad F, Bunck MC, Gooren L (2009) Fifty-two-week treatment with diet and exercise plus transdermal testosterone reverses the metabolic syndrome and improves glycemic control in men with newly diagnosed type 2 diabetes and subnormal plasma testosterone. J Androl 30: 726-733.

Singhera M, Huddart R (2013) Comment on 'Prevalence of the metabolic syndrome and cardiovascular disease risk in chemotherapytreated testicular germ cell tumour survivors'. Br J Cancer 109: 2502-2503.

Jones TH, Arver S, Behre HM, Buvat J, Meuleman E, Moncada I, Morales AM, Volterrani M, Yellowlees A, Howell JD, Channer KS (2011) Testosterone replacement in hypogonadal men with type 2 diabetes and/or metabolic syndrome (the TIMES2 study). Diabetes Care 34: 828-837.

Kapoor D, Goodwin E, Channer KS, Jones TH (2006) Testosterone replacement therapy improves insulin resistance, glycaemic control, visceral adiposity and hypercholesterolaemia in hypogonadal men with type 2 diabetes. Eur J Endocrinol 154: 899-906.

Marin P, Holmang S, Gustafsson C, Jonsson L, Kvist H, Elander A, Eldh J, Sjostrom L, Holm G, Bjorntorp P (1993) Androgen treatment of abdominally obese men. Obes Res 1: 245-251.

Rebuffe-Scrive M, Marin P, Bjorntorp P (1991) Effect of testosterone on abdominal adipose tissue in men. Int J Obes 15: 791-795.

Willemse PM, Burggraaf J, Hamdy NA, Weijl NI, Vossen CY, van WL, van Steijn-van Tol AQ, Rosendaal FR, Osanto S (2013) Prevalence of the metabolic syndrome and cardiovascular disease risk in chemotherapy-treated testicular germ cell tumour survivors. Br J Cancer 109: 60-67.

This work is licensed under the Creative Commons Attribution-NonCommercial-Share Alike 3.0 Unported License. To view a copy of this license, visit http://creativecommons. org/licenses/by-nc-sa/3.0/ 